\title{
Species composition and abundance of the oribatid fauna (Acari, Oribatida) at two lakes in the Floyen area, Bergen, Norway
}

\author{
ANNA SENICZAK ${ }^{1}$, TORSTEIN SOLHØY ${ }^{2}$, STANISŁAW SENICZAK ${ }^{1}$ \\ and ARGUITXU DE LA RIVA-CABALLERO ${ }^{2},{ }^{3}$ \\ ${ }^{1}$ Department of Ecology, University of Technology and Life Sciences, Ks. Kordeckiego 20, \\ 85-225 Bydgoszcz, Poland \\ ${ }^{2}$ Department of Biology, University of Bergen, P.O.Box 7803, N-5020 Bergen, Norway \\ ${ }^{3}$ Bergen Museum, University of Bergen, Thormølensgate 53 a, P.O.Box 7800, N-5020 Bergen, Norway \\ Corresponding author: Anna Seniczak, aseniczak@utp.edu.pl
}

(Received on 30 January 2008; Accepted on 23 March 2009)

\begin{abstract}
Oribatid communities from the edges of two lakes in the Fløyen area, Bergen, Norway, were compared in June 2005. The lower lake, Blåmansvannet (412 m a.s.1.), is surrounded by spruce forest, while the 'Higher Lake' (513 m a.s.1.), is above the tree line. Both lakes have a low pH and their edges are dominated by Sphagnum mosses. The abundance of total mites, as well as of Oribatida, were almost 2-fold higher at the 'Higher Lake' (51 510 and 51160 ind. $/ \mathrm{m}^{2}$, respectively), while species diversity was lower than at Blåmansvannet. On the shore of Blåmansvannet, the eudominant $(20 \%<D \leq 40 \%)$ species was Trimalaconothrus maior, while Liochthonius peduncularis, Limnozetes ciliatus, and Nanhermannia cf. coronata were dominant $(10 \%<\mathrm{D} \leq 20 \%)$. At 'Higher Lake', the eudominant species was Limnozetes ciliatus, which reached a 4-fold higher abundance (15 $\left.930 \mathrm{ind} . / \mathrm{m}^{2}\right)$ than at Blåmansvannet, and dominant species were Liochthonius alpestris, Nanhermannia cf. coronata, and Platynothrus punctatus. At both lakes, juveniles made up about $30 \%$ of all oribatids. Four species are new to Norway: Ceratoppia sexpilosa, Liochthonius alpestris, Liochthonius peduncularis, and Trhypochthoniellus longisetus.
\end{abstract}

Keywords: Acari, Oribatida, bog, Sphagnum, altitude, Norway

\section{INTRODUCTION}

Oribatid mites are found mainly in terrestrial habitats, but include some species that are well adapted to freshwater and semi-aquatic environments. About 90 species worldwide (less than 1\% of all known oribatid species) from 10 genera (Mucronothrus, Trhypochthoniellus, Aquanothrus, Chudalupia, Tegeocranellus, Hydrozetes, Limnozetella, Limnozetes, Heterozetes, Zetomimus) can be considered truly aquatic (Schatz \& Behan-Pelletier 2008). In bogs, oribatid mites are the most abundant and diverse group of microarthropods (BELANGER 1976), and are an important group for understanding the functioning of these ecosystems. 
In Scandinavia, the oribatid fauna of bogs has been studied in Finland by KARPPINEN (1955a; 1955b; 1958; 1972; 1977) and MARKKULA (1981; 1982; 1986a; 1986b), in Sweden by Tarras-Wahlberg $(1952 ; 1954 ; 1961)$ and Dalenius $(1960 ; 1962)$, and in Norway by Solhøy $(1976 ; 1979)$ and Riva-CABallero (2003). The aim of this study is to describe and compare the oribatid fauna at the shores of two lakes, from tree zone and above it in western Norway.

\section{STUDY AREA}

Blåmansvannet is located at $412 \mathrm{~m}$ a.s.1., 60²4'58”N $5^{\circ} 21^{\prime} 31^{\prime \prime} \mathrm{E}$. The area around Blåmansvannet is swamp/bog with Norwegian spruce (Picea abies (L.) Karst.) and planted Sitka spruce (Picea sitchensis (Bong.) as the main trees in the area, together with some mountain birch (Betula pubescens Ehrh.). The other lake, referred to as the 'Higher Lake', is located at $513 \mathrm{~m}$ a.s.1., $60^{\circ} 24^{\prime} 05^{\prime \prime} \mathrm{N}, 5^{\circ} 21^{\prime} 49^{\prime \prime} \mathrm{E}$, above the tree line (450 $\mathrm{m}$ a.s.1.).

The climate of the area is oceanic: high precipitation, cool summers, and mild winters. The rather variable topography of the area creates numerous microclimates in the local ecosystems, while the high rainfall makes it rich in brook and lake systems (Fossen et al. 1986).

The bedrock in the study area is gneiss, a metamorphic rock that gives an acidic character to soil and water, which limits plant diversity (MoE 1995). Both lakes have a low $\mathrm{pH}$ (5.2 and 5.5, respectively) and their littoral zone is rather steep, without any submerged plants growing along the shore.

\section{MATERIAL AND METHODS}

Samples of Sphagnum moss were taken from the shores of two lakes located in the Fløyen area, Bergen, Norway, on 6 June 2005. At each lake, 5 samples of Sphagnum (each covering an area of $20 \mathrm{~cm} \times 20 \mathrm{~cm}$ and $5 \mathrm{~cm}$ deep) were taken from the water edge. Mites were extracted using a modified Berlese-Tullgren funnel. In total, 16054 mites were extracted, including 15859 Oribatida (Blåmansvannet: 5 627; 'Higher Lake': 10 232). Oribatida were determined to species, including juvenile stages, except for Liochthonius spp. due to a great similarity of tritonymphs and freshly moulted adults. Nomenclature follows SubíAs (2004) and partly WEIGMANN (2006). For each oribatid species, we estimated abundance $\left(\mathrm{A}=\right.$ individuals per $\left.\mathrm{m}^{2}\right)$, constancy $(\mathrm{C}=\%$ of samples), dominance $(\mathrm{D}=\%$ of total oribatid mites), and age structure (Tables 1, 2 and 3). The classes of dominance follow SENICZAK (1978).

\section{RESULTS}

At both lakes, Oribatida were highly dominant, making up over $95 \%$ of total Acari (Table 1). The abundance of mites, as well as of Oribatida, was almost twice as high, while species diversity was lower at the 'Higher Lake' than at Blåmansvan- 
Table 1. Abundance $\left(A\right.$, in $\left.10^{3} \mathrm{ind} . / \mathrm{m}^{2}\right)$ and diversity of Oribatida and total mites (Acari) in the studied lakes. $\mathrm{SD}=$ standard deviation

\begin{tabular}{lccc}
\hline Index & & Blåmansvannet & 'Higher Lake' \\
\hline Adult Oribatida abundance & mean & 18.81 & 37.47 \\
& range & $14.68-21.20$ & $19.62-64.22$ \\
& SD & 2.53 & 17.31 \\
\hline Juvenile Oribatida abundance & mean & 9.33 & 13.70 \\
& range & $4.65-15.35$ & $6.65-19.02$ \\
& SD & 4.12 & 4.56 \\
\hline Total Oribatida abundance & mean & 28.14 & 51.16 \\
& range & $21.25-33.83$ & $34.27-83.25$ \\
& SD & 5.12 & 18.86 \\
\hline Acari abundance & mean & 28.77 & 51.51 \\
& range & $21.65-34.23$ & $34.32-84.45$ \\
& SD & 5.31 & 19.32 \\
\hline Oribatida species number & & 37 & 26 \\
\hline Shannon index & & 2.362 & 2.209 \\
\hline
\end{tabular}

net. The dominance structure of species differed between the lakes. On the shore of Blåmansvannet, the eudominant species $(20 \%<D \leq 40 \%)$ was Trimalaconothrus maior (Berlese, 1910), accompanied by 3 dominant species $(10 \%<\mathrm{D} \leq 20 \%)$ : Liochthonius peduncularis (Strenzke, 1951), Limnozetes ciliatus (Schrank, 1803), and Nanhermannia cf. coronata (Banks, 1896) (Table 2). At the 'Higher Lake', Limnozetes ciliatus was eudominant, with a density 4-fold higher than at Blåmansvannet. The dominant species were Liochthonius alpestris (Forsslund, 1958), Nanhermannia cf. coronata, and Platynothrus punctatus (L. Koch, 1879).

The age structure was similar at both altitudes, and juveniles made up about $30 \%$ of all oribatid mites. Species of the family Nothridae, Platynothrus punctatus and Nothrus pratensis Sellnick, 1928, were represented mostly by juvenile stages (Table 3 ). In contrast, juveniles from the genera Limnozetes and Hydrozetes made up only a small fraction of the population. For Nanhermannia cf. coronata and in the genus Trimalaconothrus, the participation of adults and juveniles in age structure was similar.

\section{DISCUSSION AND CONCLUSIONS}

The increase in altitude by $100 \mathrm{~m}$ leads to a mean temperature drop of $0.6^{\circ} \mathrm{C}$ (KÖRNER 2003) and is one of the main factors that govern the vertical distribution of 
Table 2. Abundance $\left(A\right.$, in $10^{3}$ ind. $\left./ \mathrm{m}^{2}\right)$, constancy $(C=\%$ of samples $)$ and dominance $(D=\%$ of total oribatid mites) of individual species of Oribatida in the studied lakes

\begin{tabular}{|c|c|c|c|c|c|c|}
\hline \multirow[t]{2}{*}{ Species } & \multicolumn{3}{|c|}{ Blåmansvannet } & \multicolumn{3}{|c|}{ 'Higher Lake' } \\
\hline & $A$ & $C$ & $D$ & $A$ & $C$ & $D$ \\
\hline Atropacarus striculus (C. L. Koch, 1835) & 0.29 & 100 & 1.03 & 0.58 & 100 & 1.12 \\
\hline Banksinoma lanceolata (Michael, 1885) & 0.03 & 40 & 0.11 & 0.09 & 60 & 0.18 \\
\hline Camisia solhoeyi Colloff, 1993 & 0.01 & 20 & 0.04 & 0.00 & 0 & 0.00 \\
\hline Carabodes labyrinthicus (Michael, 1879) & 0.01 & 40 & 0.04 & 0.00 & 0 & 0.00 \\
\hline Carabodes willmanni Bernini, 1975 & 0.00 & 0 & 0.00 & 0.02 & 40 & 0.03 \\
\hline Ceratoppia sexpilosa Willmann, 1938 & 0.01 & 20 & 0.04 & 0.00 & 0 & 0.00 \\
\hline Chamobates pusillus (Berlese, 1895) & 0.03 & 40 & 0.11 & 0.00 & 0 & 0.00 \\
\hline Eueremaeus oblongus (C. L. Koch, 1835) & 0.01 & 20 & 0.02 & 0.00 & 0 & 0.00 \\
\hline Eupelops plicatus (C. L. Koch, 1835) & 0.02 & 60 & 0.05 & 0.01 & 40 & 0.02 \\
\hline Fuscozetes fuscipes (C. L. Koch, 1844) & 0.58 & 100 & 2.06 & 0.07 & 40 & 0.13 \\
\hline Hemileius initialis (Berlese, 1908) & 0.08 & 40 & 0.27 & 0.06 & 60 & 0.11 \\
\hline Hydrozetes lacustris (Michael, 1882) & 0.90 & 100 & 3.18 & 0.35 & 80 & 0.68 \\
\hline Hydrozetes octosetosus Willmann, 1932 & 0.52 & 100 & 1.85 & 0.11 & 80 & 0.22 \\
\hline Hypochthonius rufulus C. L. Koch, 1835 & 0.01 & 40 & 0.04 & 0.26 & 80 & 0.50 \\
\hline Limnozetes ciliatus (Schrank, 1803) & 3.62 & 100 & 12.87 & 15.93 & 100 & 31.14 \\
\hline Limnozetes rugosus (Sellnick, 1923) & 0.88 & 100 & 3.13 & 1.00 & 100 & 1.95 \\
\hline Liochthonius alpestris (Forsslund, 1958) & 0.98 & 100 & 3.48 & 9.44 & 100 & 18.44 \\
\hline Liochthonius peduncularis (Strenzke, 1951) & 4.61 & 100 & 16.37 & 3.75 & 100 & 7.32 \\
\hline Malaconothrus monodactylus (Michael, 1888) & 0.05 & 40 & 0.16 & 1.29 & 100 & 2.51 \\
\hline Moritzoppia neerlandica (Oudemans, 1900) & 0.04 & 80 & 0.12 & 0.00 & 0 & 0.00 \\
\hline Mucronothrus nasalis (Willmann, 1929) & 0.82 & 80 & 2.91 & 0.67 & 60 & 1.30 \\
\hline Mycobates sarekensis (Tragardh, 1910) & 0.01 & 20 & 0.02 & 0.00 & 0 & 0.00 \\
\hline Nanhermannia cf. coronata (Banks, 1896) & 3.37 & 100 & 11.96 & 5.38 & 100 & 10.51 \\
\hline Nothrus pratensis Sellnick, 1928 & 0.61 & 100 & 2.17 & 2.39 & 80 & 4.67 \\
\hline Oppiella nova (Oudemans, 1902) & 0.04 & 40 & 0.12 & 0.92 & 40 & 1.80 \\
\hline Parachipteria willmani Hammen, 1952 & 0.02 & 40 & 0.05 & 0.02 & 20 & 0.04 \\
\hline Phauloppia lucorum (C. L. Koch, 1841) & 0.01 & 20 & 0.02 & 0.00 & 0 & 0.00 \\
\hline Phthiracarus italicus (Oudemans, 1900) & 0.08 & 20 & 0.27 & 0.00 & 0 & 0.00 \\
\hline Phthiracarus laevigatus (C. L. Koch, 1841) & 0.02 & 20 & 0.05 & 0.00 & 0 & 0.00 \\
\hline Platynothrus punctatus (L. Koch, 1879) & 0.67 & 100 & 2.36 & 5.01 & 100 & 9.79 \\
\hline Quadroppia quadricarinata (Michael, 1885) & 0.01 & 20 & 0.04 & 0.00 & 0 & 0.00 \\
\hline Suctobelbella palustris (Forsslund, 1953) & 0.01 & 20 & 0.02 & 0.00 & 0 & 0.00 \\
\hline Suctobelbella similis (Forsslund, 1941) & 0.06 & 40 & 0.21 & 0.01 & 20 & 0.01 \\
\hline Tectocepheus velatus (Michael, 1880) & 0.04 & 40 & 0.14 & 0.01 & 40 & 0.02 \\
\hline Trhypochthoniellus longisetus (Berlese, 1904) & 0.07 & 40 & 0.23 & 0.78 & 100 & 1.52 \\
\hline Trimalaconothrus foveolatus Willmann, 1931 & 0.48 & 100 & 1.69 & 2.30 & 100 & 4.49 \\
\hline Trimalaconothrus angulatus (Michael, 1888) & 1.78 & 100 & 6.31 & 0.27 & 80 & 0.53 \\
\hline Trimalaconothrus maior (Berlese, 1910) & 7.45 & 100 & 26.48 & 0.50 & 100 & 0.98 \\
\hline
\end{tabular}


Table 3. Mean abundance $\left(A\right.$, in 103 ind. $\left./ \mathrm{m}^{2}\right)$ and percentage of adults and juveniles of some Oribatida (with $D>1$ and represented by adults and juveniles) at the studied lakes. Ad = adults; Juv = juveniles

\begin{tabular}{|c|c|c|c|c|c|}
\hline \multirow[t]{2}{*}{ Species } & & \multicolumn{2}{|c|}{ Blåmansvannet } & \multicolumn{2}{|c|}{ 'Higher Lake' } \\
\hline & & mean & $\%$ & mean & $\%$ \\
\hline \multirow[t]{2}{*}{ Fuscozetes fuscipes } & Ad & 0.11 & 19 & 0.02 & 29 \\
\hline & Juv & 0.47 & 81 & 0.04 & 71 \\
\hline \multirow[t]{2}{*}{ Hydrozetes lacustris } & $\mathrm{Ad}$ & 0.69 & 77 & 0.32 & 91 \\
\hline & Juv & 0.21 & 23 & 0.03 & 9 \\
\hline \multirow[t]{2}{*}{ Hydrozetes octosetosus } & Ad & 0.40 & 77 & 0.11 & 100 \\
\hline & Juv & 0.12 & 23 & 0.00 & 0 \\
\hline \multirow[t]{2}{*}{ Limnozetes ciliatus } & Ad & 3.11 & 86 & 13.48 & 85 \\
\hline & Juv & 0.52 & 14 & 2.45 & 15 \\
\hline \multirow[t]{2}{*}{ Limnozetes rugosus } & Ad & 0.82 & 93 & 0.91 & 91 \\
\hline & Juv & 0.06 & 7 & 0.09 & 9 \\
\hline \multirow[t]{2}{*}{ Mucronothrus nasalis } & Ad & 0.56 & 68 & 0.19 & 28 \\
\hline & Juv & 0.27 & 32 & 0.47 & 72 \\
\hline \multirow[t]{2}{*}{ Nanhermannia cf. coronata } & Ad & 1.79 & 53 & 3.27 & 61 \\
\hline & Juv & 1.58 & 47 & 2.11 & 39 \\
\hline \multirow[t]{2}{*}{ Nothrus pratensis } & Ad & 0.18 & 29 & 0.33 & 14 \\
\hline & Juv & 0.44 & 71 & 2.07 & 86 \\
\hline \multirow[t]{2}{*}{ Platynothrus punctatus } & Ad & 0.10 & 15 & 0.70 & 14 \\
\hline & Juv & 0.57 & 85 & 4.31 & 86 \\
\hline \multirow[t]{2}{*}{ Trhypochthoniellus longisetus } & Ad & 0.03 & 43 & 0.77 & 99 \\
\hline & Juv & 0.04 & 57 & 0.01 & 1 \\
\hline \multirow[t]{2}{*}{ Trimalaconothrus foveolatus } & Ad & 0.30 & 62 & 1.15 & 50 \\
\hline & Juv & 0.18 & 38 & 1.15 & 50 \\
\hline \multirow[t]{2}{*}{ Trimalaconothrus angulatus } & Ad & 0.90 & 51 & 0.15 & 51 \\
\hline & Juv & 0.88 & 49 & 0.13 & 49 \\
\hline \multirow[t]{2}{*}{ Trimalaconothrus maior } & Ad & 3.55 & 48 & 0.30 & 59 \\
\hline & Juv & 3.91 & 52 & 0.21 & 41 \\
\hline
\end{tabular}

plants in the mountains. The general trend that species diversity decreases with increasing altitude (e.g. GASTON 2000) could also be seen in the present study. On the shore of the 'Higher Lake', the number of oribatid species was lower but the density was higher than on the shore of Blåmansvannet. An increase in altitude and lack of trees around the lake are undoubtedly a challenge for some oribatid mites, similarly to very dry or very wet habitats. For example, the number of oribatid species in bogs declined when moisture increased from moderate towards saturated conditions (EITMINAVIČIŪTĖ 1966; Donaldson 1996; SeniczaK et al. 2006). Concomitantly, the total density of Oribatida increased, as those few species that tolerated a very wet microhabitat occurred in much higher densities. This is consistent with the results of BORCARD (1991), who 
studied oribatid bog communities in Switzerland and found that species with a wide tolerance were less abundant, while specialized species were locally very abundant. In our study the species diversity of Oribatida at the edges of both lakes was rather low, in agreement with the results of the studies mentioned above.

Altitude affects not only species richness but also species composition, as shown, for example, for insects. Species vary in their population response to altitude, some showing increasing, declining or no altitudinal trends in abundance (HoDKINSON 2005). At Blåmansvannet, the majority of species was represented by a single specimen each $\left(89 \%\right.$ of species with density $<2000$ ind. $\left./ \mathrm{m}^{2}\right)$. Many of them were typical forest species. Trimalaconothrus maior was the most abundant species and Limnozetes ciliatus, Liochthonius peduncularis and Nanhermannia cf. coronata were relatively abundant. At the 'Higher Lake', 73\% of species had a density $<2000$ ind. $/ \mathrm{m}^{2}$. Limnozetes ciliatus occurred in large numbers and made up $30 \%$ of all oribatid mites, while several other species that can also be classified as hydrophilic (Liochthonius alpestris, Nanhermannia cf. coronata, Platynothrus punctatus, Nothrus pratensis, Liochthonius peduncularis, Trimalaconothrus foveolatus) were relatively abundant there. Limnozetes ciliatus is a typical species found near ponds (BEHAN-PELLETIER 1989; BORCARD 1997) and it was also most abundant close to the edges of the lobelia lake Wielkie Gacno in the Tuchola Forest (Bory Tucholskie) in Poland (SENICZAK et al. 2006). In contrast, species from the genera Limnozetes, Hydrozetes and Trimalaconothrus were not present in samples collected from Uksetjern, an oligotrophic bog in western Norway, probably because the habitat was not wet enough (SoLHøy 1979).

At a fen in southern Lithuania, the most abundant species at the water edge was Hydrozetes lacustris (Michael, 1882) (EITMINAVIČIŪTĖ 1966). In our study, species from this genus had a rather low density, which was probably caused by the absence of submerged plants along the shores. In studies carried out in Poland, Hydrozetes lemnae (Coggi, 1899) was abundant at a lake that had a well-developed Carex belt (SENICZAK et al. 2007).

The density of Oribatida on the lakeshores at Fløyen is comparable with that at Spruce Hole Bog in New Hampshire, U.S.A. (DonALDSON 1996), but several-fold lower than on the shore of the dystrophic Lake Martwe in the Tuchola Forest, Poland (SENICZAK et al. 2007). The latter sites are located at a much lower elevation than Fløyen, and they certainly differ in water $\mathrm{pH}$ and probably also in other environmental variables. The acidity of water is a very important factor that affects oribatid mite density and species composition (Walgram 1976; Behan-Pelletier \& Bisset 1994; SENICZAK et al. 2007), while knowledge about other factors is still very limited. Further studies of the acarofauna of bogs are needed to understand the ecological preferences of individual species. Such knowledge could be important for bioindication, in particular in bog areas, which are sensitive, threatened ecosystems, and require care and conservation.

From the obtained results the following conclusions can be drawn:

1. At Blåmansvannet the density of mites, including the Oribatida, was distinctly lower, and oribatid mites were richer in species than at the 'Higher Lake'.

2. Species dominance differed between the lakes: at Blåmansvannet, Trimalaconothrus maior was eudominant, while at the 'Higher Lake', Limnozetes ciliatus. 
Nanhermannia cf. coronata was dominant at both lakes. Moreover, at Blåmansvannet Liochthonius peduncularis and Limnozetes ciliatus were dominant, whereas at the 'Higher Lake', Liochthonius alpestris and Platynothrus punctatus.

3. Based on the species list of MeHL (1979) and subsequent publications, new to the Norwegian fauna are: Ceratoppia sexpilosa Willmann, 1938, Liochthonius alpestris, Liochthonius peduncularis and Trhypochthoniellus longisetus (Berlese, 1904).

Acknowledgements: The visit of A.S. to the University of Bergen was founded by a grant from the Norwegian Research Council. We are grateful to Cathy Jenks, Department of Biology, University of Bergen, Norway, for linguistic corrections and improvement of the manuscript.

\section{REFERENCES}

Behan-Pelletier V. M. 1989. Limnozetes (Acari: Oribatida: Limnozetidae) of northeastern North America. Can. Ent. 121: 453-506.

Behan-Pelletier V. M., Bisset B. 1994. Oribatida of Canadian peatlands. Mem. Entomol. Soc. Can. 169: 73-88.

Belanger S. D. 1976. The Microarthropod community of Sphagnum moss with emphasis on the Oribatei. Unpubl. M. Sc. thesis, State University of New York, Syracuse, N. Y. 80 pp.

Borcard D. 1991. Les Oribates des tourbiéres du Jura suisse (Acari, Oribatei): Ecologie I. Quelques aspects de la communauté d'Oribates des sphaignes de la tourbiére du Cachot [Oribatida of the bogs of the Swiss Jura (Acari, Oribatei): Ecology I. Some aspects of the oribatid community of peat bogs in Cachot]. Rev. Suisse Zool. 98: 303-317 (in French).

Borcard D. 1997. Oribatid mites in peat-bog remnants of the Swiss Jura mountains. Abh. Ber. Naturkundemus. Görlitz 69: 19-23.

Dalenius P. 1960. Studies on the Oribatei (Acari) of the Tornetrask Territory in Swedish Lappland. I. A list of the habitats, and the composition of their oribatid fauna. Oikos 11: 80-124.

Dalenius P. 1962. Studies on the Oribatei (Acari) of the Tornetrask Territory in Swedish Lappland. III. The vertical distribution of the moss mites. Kungl. Fysiogr. Sällsk. und Förhandl. 32: $105-129$.

Donaldson G. M. 1996. Oribatida (Acari) associated with three species of Sphagnum at Spruce Hole Bog, New Hampshire, U.S.A. Can. J. Zool. 74: 1713-1720.

EITMINAVIČIŪTĖ I. 1966. Oribatidy bieriegov zabločennych ozier (1. Nizinnoje boloto) [Orbitada of peaty lake shores (1. Fens)]. Lietuvos TSR Mokslų akademijos darbai. Series C 1(39): 53-62 (in Russian).

Fossen A. B., Greve H. S., Kobbeltvedt O., Slettebø M. B., Vassenden O. J. 1986. From the Ice Age to nowadays. In: The mountain world of Bergensers (Fossen A.B., KobBeltvedt O., Eds), vol. 1, 1986-1988 Hardanger forlag 296 pp (in Norwegian).

Gaston K. J. 2000. Global patterns in biodiversity. Nature 405: 220-227.

Hodkinson I. D. 2005. Terrestrial insects along elevation gradients: species and community responses to altitude. Biol. Rev. 80: 489-513.

KARPPINEN E. 1955a. Ecological and transect survey studies on Finnish Camisiidae (Acar., Oribatei). Ann. Zool. Soc. 'Vanamo' 17(2): 1-80.

KarPpinen E. 1955b. Die Oribatiden-Fauna eines Corylus avallana Gebüsches und eines Sumpfmoores in Tvärminne, Südfinnland [The oribatid fauna of Corylus avallana bushes and a swamp in Tvärminne, Southern Finland]. Arch. Soc. Zool. Bot. Fenn. 'Vanamo', 9, Suppl: 131-134 (in German). 
KARPPINEN E. 1958. Untersuchungen über die Oribatiden (Acar.) der Waldböden von Hyloconium-Myrtillus-Typ in Nordfinnland [Studies of the oribatid mites (Acar.) of forest soils of Hyloconium-Myrtillus type in Northern Finland]. Ann. Entomol. Fenn. 24: 149-168 (in German).

KARPPINEN E. 1972. Studies on the oribatid fauna of spruce-hardwood peatlands in southern Finland. I. (Arach., Acari). Ann. Entomol. Fenn. 38: 96-99.

KARPPINEN E. 1977. Studies on the oribatid fauna of spruce-hardwood peatlands in southern Finland. II. Ann. Entomol. Fenn. 43: 81-86.

KöRNER C. 2003. Alpine plant life. Functional plant ecology of high mountain ecosystems, $2^{\text {nd }}$ Edition. Springer, pp. 344.

MARKKULA I. 1981. Vertical distribution of soil animals in a virgin and drained raised bog. SUO 32: $126-129$.

MARKKULA I. 1982. Effect of drainage and NPK-fertilization on soil animals of a raised bog. SUO 33: $55-63$.

MARKKULA I. 1986a. Comparison of the communities of oribatids (Acari: Cryptostigmata) of virgin and forest ameliorated pine bogs. Ann. Zool. Fenn. 23: 33-38.

MarkKula I. 1986b. Comparison of present and subfossil oribatid faunas in the surface peat of a drained pine mire. Ann. Entomol. Fenn. 52: 39-41.

Ment R. 1979. Checklist of Norwegian ticks and mites (Acari). Fauna Norv. 26B: 31-45.

MoE B. 1995. Studies of the alpine flora along an east-west gradient in central Western Norway. Nord. J. Bot. 15: 77-89.

Riva-Caballero A. De La 2003. Oribatid mite communities in bogs along an altitudinal gradient and palaeoecological reconstruction using fossil oribatid mites in Western Norway. Unpubl. M. Sc. thesis, University of Bergen, Norway, $67 \mathrm{pp}$.

Schatz H., Behan-Pelletier V. M. 2008. Global diversity of oribatids (Oribatida: Acari: Arachnida). Hydrobiologia 595: 323-328.

SenICZAK S. 1978. Studia młodociane mechowców (Acari, Oribatei) jako istotny składnik zgrupowań tych roztoczy przetwarzających glebową substancję organiczną [Juvenile stages of moss mites (Acarina, Oribatei) as an essential component of agglomerations of these mites transforming the organic matter of soil]. Uniwersytet Mikołaja Kopernika, Torun, pp. 171 (in Polish).

Seniczak S., Bukowski G., Seniczak A., Bukowska H. 2006. The soil Oribatida (Acari) of the ecotones between the Scots pine forest and lakes in the National Park Bory Tucholskie. Biological Lett. 43: 221-225.

Seniczak A., Seniczak S., Nowicka A. 2007. Roztocze (Acari) strefy brzegowej dwóch jezior śródleśnych o różnej jakości wody, w Borach Tucholskich [The mites (Acari) of the water edge of two forest ponds with different water quality in the Tuchola Forest]. Zootechnika 36: 31-38 (in Polish).

Solнøy T. 1976. Dynamics of Oribatei populations on Hardandervidda. In: Fennoscandian Tundra Ecosystems (Wielgolaski F. E., Ed). Part 2, pp. 60-65, Animals and Systems Analysis. Springer-Verlag, Berlin.

Solнøy T. 1979. Oribatids (Acari) from an oligotrophic bog in western Norway. Fauna Norv. 26B: 91-94.

SuBíAS L. S. 2004. Systematic, synonymic and biogeographical check- list of the world's oribatid mites (Acariformes, Oribatida) (1758-2002). Graellsia 60: 3-305.

TARras-Wahlberg N. 1952. Oribatids from mires in Småland. Kungl. Fysiogr. Sällsk. Lund. Förhandl. 22: 1-4.

TARras-Wahlberg N. 1954. Oribatids from the Akhult mire. Oikos 4: 166-171.

TARRAs-WAhlBerg N. 1961. The Oribatei of a central Swedish bog and their environment. Oikos Suppl. 4: 1-54. 
Walgram M. 1976. Über die Verbreitung der wasserbewohnenden Hornmilbengattung Hydrozetes Berlese 1902 (Acari, Oribatei) in Österreich [About the distribution of aquatic oribatid species Hydrozetes Berlese 1902 (Acari, Oribatei) in Austria]. Mitt. Naturwiss. Vereins Steiermark 106: 215-219 (in German).

Weigmann G. 2006. Hornmilben (Oribatida) [Oribatid mites (Oribatida)]. In: Die Tierwelt Deutschland und der angrenzenden Meeresteile (DAHL F., Ed). 76. Teil. Goecke \& Evers, Keltern, pp. 1-520 (in German). 